\title{
QUALITATIVE INVESTIGATION INTO CONSUMER MOTIVATIONS AND ATTITUDES TOWARDS RESEARCH SHOPPING IN THE GEORGIAN MARKET
}

\author{
JAKOŚCIOWE BADANIE MOTYWACJI I POSTAW KONSUMENCKICH WOBEC \\ BADAŃ W ZAKRESIE ZAKUPÓW NA RYNKU GRUZIŃSKIM
}

https://doi.org/10.34739/zn.2019.48.04

\section{Tornike Khoshtaria ${ }^{1}$ \\ Arian Matin ${ }^{2}$}

\author{
${ }^{1}$ Georgia, Samtskhe-Javakheti State University, Faculty of Business administration \\ European University, Faculty of Business and Technologies \\ ORCID: 0000-0002-6018-4337, e-mail: tkhoshtaria@eu.edu.ge \\ 2 Georgia, International Black Sea University \\ ORCID: 0000-0003-4497-4651, e-mail: arianmatin@outlook.com
}

\begin{abstract}
This study aims to discover different levels of research shopping behavior among Georgian consumers. It adopted a deductive approach by selecting the relevant models of customer behaviour from past papers and testing them in the Georgian market. In order to find the main themes associated with research shopping, five focus groups were held using exploratory and semi-structured questions. The responses were analyzed on the basis of two main customer motivations, utilitarian and hedonistic, in order to find the roots of each factor in consumer's minds. The results indicate the important roles factors such as the retail sector, price, immediate product availability and staff training play in research shopping behaviour in the market. This research approaches the shopping motivations in a novel manner by connecting those roots to two other elements which are the retail sector and the nature of the retail outlet.

Keywords: consumer behavior, show-rooming, web-rooming, utilitarian shopping values, hedonistic shopping values

Streszczenie: Opracowanie to ma na celu ukazanie różnych aspektów badań w zakresie zachowań zakupowych wśród gruzińskich konsumentów. W artykule przyjęto podejście dedukcyjne, wybierając odpowiednie modele zachowań klienta ze źródeł wtórnych i testowanie ich na rynku gruzińskim. W celu wyodrębnienia zagadnień związanych z tematem badania zorganizowano pięć grup fokusowych przy użyciu pytań eksploracyjnych i pytań częściowo ustrukturyzowanych. Odpowiedzi przeanalizowano na podstawie dwóch głównych przesłanek motywujących klientów do zakupów, tj. przesłanek utylitarnych i hedonistycznych, tak aby zidentyfikować motywy każdej z przesłanek u konsumenta. Wyniki wskazują iż czynniki, takie jak sektor detaliczny, cena, natychmiastowa dostępność produktów i szkolenie personelu odgrywają ważna rolę w zachowaniach zakupowych konsumentów. Badania podchodzą do zagadnienia motywacji zakupowych w nowatorski sposób, łącząc motywy do podjęcia przesłanek zakupowych z dwoma innymi elementami, takim jak sektor detaliczny i charakter punktu sprzedaży detalicznej.
\end{abstract}

Słowa kluczowe: zachowania konsumentów, show-rooming, web-rooming, wartości użytkowe zakupów, hedonistyczne wartości zakupów

\section{Introduction}

Research shopping is not a new phenomenon in the retailing industry. It has existed for decades and caused more intense competition among retailers. However, nowadays with the expansion of outlets and retailers finding new channels to offer their products to customers more conveniently, research shopping has become more of a prominent element in the market which urges retailers to develop strategies to counter or to take advantage of the new phenomenon

One side of research shopping, called showrooming, has caused more pressure on physical and multi-channel retailers in recent years. Consumers, who inspect the products in the physical store but make their final purchase online, pushed these retailers to find ways to retain or 
Tornike K., Arian M., QUALITATIVE INVESTIGATION INTO CONSUMER MOTIVATIONS AND ATTITUDES TOWARDS RESEARCH SHOPPING IN THE GEORGIAN MARKET, Zeszyty Naukowe Uniwersytetu Przyrodniczo-Humanistycznego w Siedlcach Nr 121, Seria: Administracja i Zarządzanie (48) 2019

encourage the opposite behaviour in the market. (Yrjölä, 2014) found at least two-third of mobile owners has engaged in research shopping behaviour in price comparison between online and offline outlets.

In predicting and forming a pattern for research shopping behaviour, it is helpful to note some of the main motivational theories involved in the process. One of the main factors that can sway customers both ways, in show-rooming or web-rooming directions, are utilitarian motivations associated with the immediate product availability of physical stores according to (Herring et al., 2014) as well as personal services of the brick-and-mortar firms with face-to-face salespeople suggested by (Rigby, 2011). As opposed to the convenience and speed of online purchases as well as a broader merchandise mix of online platforms compared to physical stores noted by (Sahney et al., 2013).

Meanwhile, the Hedonic view of customers' research shopping behaviour, found by Sahney, considers the gratification of excitement, social gatherings and escapism as main factors pushing customers to switch to physical stores and treat the shopping experience as an event. While, perceived innovativeness of online retailers, fewer obligations and more control over the purchase process and lack of peer and social pressure can act as Hedonic motivators for customers to switch to online retailers.

\section{Review of literature}

(Nesar and Sabir, 2016) offered the roots of research shopping behaviour in the factors that push customers to switch between different channels. The results point to the importance of instore discounts and promotion strategy as well as return policy in customers switching to physical stores. Meanwhile, the convenience of online shopping and 24 hour availability of these outlets encourages show-rooming behaviour. Thus, these factors need to be raised and evaluated for the customers in the Georgian market to clarify their importance and attitudes towards these switching roots.

Other factors which contribute to the increase in research shopping behaviour in customers are summarised by (Menon and Kahn, 2002). The study indicates factors such as reviews and ratings, paving the way for switching outlets since they act as reassurances for customers by presenting how their peers perceive the product. Additionally, customers engage in research shopping behaviour in order to avoid post-purchase dissonance.
Meanwhile, one element that can work both ways in shaping customer research shopping behaviour is the efficiency of salespeople. According to (Rapp et al. 2015), if the retailer's salespeople are not trained and customer service is not designed properly, it can positively impact the increase in research shopping behaviour. However, well-trained staff that are equipped with skills to retain and create a comfortable atmosphere for the customers, negatively affect that growth in showrooming behaviour and hence assist less volatility for the retailer in sales levels in each outlet.

Furthermore, (Nesar and Bin Sabir, 2016) categorised research shoppers and found in addition to price-sensitive customers and exploiters in the market, who are more likely to conduct showrooming or web-rooming behaviour, whom can be controlled by high-low pricing on the retailer's part, these are another category of shoppers classified as Savvy. For this class of shopper, experience is the most important element. They consider shopping a pass time and therefore are more likely to treat research shopping as a recreational exercise rather than a purely economic practice. The roots and logic behind this category are further examined in the interviews in this study.

Although the nature and attitude of the customer in research shopping behaviour can be classified by the products as well, as (Wu et al., 2015) pointed out, there are some categories of products, classified as non-show rooming products, in which research shopping does not yield many benefits to consumers. Categories such as shopping behaviour in pharmaceuticals and personal hygiene are more rooted in brand loyalty and speciality of the store. Hence, sunk costs for consumers outweigh the benefit from showrooming behaviour. These products will be examined further with Georgian customers in this study.

Meanwhile, the degree of research shopping behaviour can be traced to customers' generic characteristics as well. Brown and Friedman and (Taran, 2013) mentioned the type of customers, who tend to conduct show-rooming and webrooming behaviour, is more likely to be younger, educated and urban. Naturally, in order to conduct research shopping and more specifically webrooming, one must be familiar with how to search for the product on the internet and find different retailers and prices. Hence a minimum knowledge of the internet and retailers ' websites are necessary for research shopping behaviour. This factor influences the sampling of this study since respondents who can participate in this study need to be familiar with the behaviour so they can be 
Tornike K., Arian M., QUALITATIVE INVESTIGATION INTO CONSUMER MOTIVATIONS AND ATTITUDES TOWARDS RESEARCH SHOPPING IN THE GEORGIAN MARKET, Zeszyty Naukowe Uniwersytetu Przyrodniczo-Humanistycznego w Siedlcach Nr 121, Seria: Administracja i Zarządzanie (48) 2019

examined in their motivations and reactions to retailers` policies.

Furthermore, customer's attitudes and perceptions can play another role in dampening the show-rooming behaviour. According to (Gensler et al., 2017), longer delivery times associated with online purchases as well as the cost of online search negatively affects show-rooming behaviour. In this case, when customers perceive the time and effort to research products online to be high, they tend to purchase in physical stores and are less likely to exhibit show-rooming behaviour. Simultaneously, consumers are required to wait for delivery of the product in online purchases, and therefore, the immediate product availability of physical stores encourages them to purchase from brick-and-mortar firms. This can cause less showrooming behaviour; however, it may result in webrooming behaviour among customers.

\section{Countermeasures}

One way to counter the behaviour in customers, suggested by (Zhang et al. 2018), is utilising sunk costs of consumers to retain them in the physical outlet and prevent switching. Naturally, for consumers whose sole purpose of visiting the physical store is show-rooming, it can be a difficult process. However, for consumers who switch causally between outlets, sunk costs such as travel, time and effort costs. Hence, by high-low pricing and proper use of promotions, retailers can enable their physical outlet to retain more customers and prevent switching.

There are other factors influencing the extent of research shopping behaviour among consumers. One of these elements can be found in the retail sector. Medium to high involvement products such as clothing and electronics involve more switching behaviour. Other factors that can negatively affect the show-rooming behaviour of customers are explored by (Mehra et al., 2017). His findings indicate that brick-and-mortar firms have two main ways to correct the show-rooming behaviour and direct it to their advantage. One short-term element proposed is price matching, which enables multichannel retailers to compete with the fast-changing and low prices of online retailers. His long term factor is in the merchandise mix where the store specialises in-store brands or private labels, which results in more exclusivity for a retailer's brand.

Hence, the effect of price matching and product assortments in the physical stores should be evaluated in the Georgian market. The extent to which these factor influence customers in the country to purchase and repurchase products in a retailer with the following characteristics can contribute to the understanding of consumer behaviour in the market.

Another element which circles back to the product assortment factor in finding the roots and countermeasures in show-rooming behaviour is the differentiation process in multi-channel retailers. (Gu and Tayi, 2016) suggest a model of horizontal product differentiation in the physical store and online outlet of an Omni-channel retailer.

His findings indicate the importance of exclusivity in merchandise mix in each outlet of the multi-channel retailer. In this case, if a customer encounters horizontally differentiated products in each outlet and does not have a precise frame of reference for show-rooming behaviour. He/she is less likely to exercise research shopping behaviour and continue with one of the outlets of a specific retailer.

Moreover, there is a broader and more complicated role for companies in today's market in pricing their products and services. (Wang and Wright, 2015) suggest based on the sector in which the firm operates and the number of platforms it offers its products and services it can take two main approaches in pricing to counter show-rooming and web-rooming behaviour. Naturally, with so many online platforms such as Amazon or eBay as well as multi-channel and physical retailers, companies have virtually global platforms to sell their products.

Hence, Wang proposed a wider price parity for specific products with global equilibrium prices and narrow price parity for products with regional significance. As an example, narrow product parity can be more useful in the hotel and accommodation sector where firms keep prices on global platforms such as Booking.com on the same level as their direct outlets. The effects and attitudes of Georgian customers toward different levels of price parity are explored more in this study through interviews.

Some aspects of research shopping behaviour can be traced back to the essence of the actions customers take to conduct the exercise. According to (Lou et al., 2014), the level of perceived behavioural control over the act of research shopping affects how often customers practice the task. Naturally, Lou's finding can be helpful for multichannel retailers with physical stores since customers perceive greater control over webrooming behaviour due to the fact that it does not require any interaction with salespeople or travel costs.

Moreover, another factor that works in favour of brick-and-mortar firms in countering the showrooming behaviour is defined by (Venkatesan et al., 2007). Their study indicates a high level of 
Tornike K., Arian M., QUALITATIVE INVESTIGATION INTO CONSUMER MOTIVATIONS AND ATTITUDES TOWARDS RESEARCH SHOPPING IN THE GEORGIAN MARKET, Zeszyty Naukowe Uniwersytetu Przyrodniczo-Humanistycznego w Siedlcach Nr 121, Seria: Administracja i Zarządzanie (48) 2019

immediate product availability in physical stores negatively affect switching behaviour among consumers. Since customers do not have to wait to examine or consume products when shopping at physical retailers, they are less likely to conduct show-rooming behaviour. However, it does not reduce the chance of web-rooming behaviour and mostly applies to customers who have little urgency in their purchase.

Not only measures such as control and promotions contribute to reducing research shopping behaviour, but some elements in the attitude of the new generation of consumers assist this process. (Donnelly and Scaff, 2013) suggest $84 \%$ of the millennial generation in the United States prefer shopping in department stores with high brand loyalty. Naturally, this attitude can be helpful in countering the level of research shopping behaviour.

As can be observed, research shopping is a broad subject with many variables involved which affect the exercise from different angles. Two main aspects of research shopping are show-rooming, which tends to negatively affect the sales of brickand-mortar firms who emphasize their physical stores more than their online outlets and webrooming, which tends to affect online retailers negatively.

Customers' motivations for each aspect differ in some parts due to deviations in the nature of show-rooming to web-rooming. Therefore, this study aims to discover the attitudes and opinions of customers in Georgia on research shopping in general and their motivations for the decisionmaking process in the subject matter. Furthermore, the study attempts to discover customer's attitudes towards show-rooming and web-rooming and find whether Georgian consumers have different incentives for conducting each one of these exercises. Moreover, how the attitudes of the customers in the country changes to each one of the countermeasures that the retailers take to combat research shopping will be examined. Hence, a qualitative method is employed to explore these attitudes towards research shopping as well as investigating customers ' responses to retailers' policies for reducing the practice.

\section{Methodology}

This study intends to explore customer attitude and motivations for research shopping through a largely deductive method. The framework is formed based on past literature, which categorises the motivations customers around the world have for research shopping and presenting the framework to
Georgian customer to find out their opinion concerning the process.

Since the research intends to discover the roots and attitudes of customers, a qualitative method is employed to investigate these elements on both emotional and rational levels for Georgian consumers. Hence, five focus groups are set up to encourage customers to participate in the discussions.

In order to test the validity and reliability of the study, a saturation method was utilised which meant starting each focus group with a few exploratory questions about the act of research shopping and allowing the respondents to freely express their thoughts and attitudes toward the phenomenon. It paved the way for researchers, to not only find whether there were any more elements to motivate customers to engage in research shopping behaviour than the factors reviewed in past literature, but also to find when the focus groups reach saturation points and no longer yield new elements in consumer attitudes.

Moreover, according to (Powell and Single, 1996) for most studies, one to ten focus groups of 90 to 120 minutes is enough to cover most themes in a subject before saturation. Guest et al., 2017) suggested three to six focus groups of shorter time periods for covering $90 \%$ of topics in a subject before replicating the same information. In this study, five focus groups were held to cover more customers with different backgrounds and attitudes from the age range to socio-economic classes as well as including residents of other countries living in Georgia. This allowed the study to cover the topic from different angles

Structurally, apart from exploratory questions, the second part of the focus groups was dedicated to a semi-structured method in which the respondents were asked to express their opinions about the elements and motivations in research shopping which the researchers reviewed in past literature. This part allowed the authors to go deeper into the attitudes of Georgian consumers for each of the elements discussed in the framework. The questions were mostly open-ended in both exploratory and semi-structured parts to persuade respondents to express their opinion as freely as possible.

The sampling was a purposeful cluster, which meant the consumers were chosen from urban areas from the millennial generation. The reason behind the sampling was to interview customers who have access to the internet and are able to place orders online woth local and international retailers. 
Tornike K., Arian M., QUALITATIVE INVESTIGATION INTO CONSUMER MOTIVATIONS AND ATTITUDES TOWARDS RESEARCH SHOPPING IN THE GEORGIAN MARKET, Zeszyty Naukowe Uniwersytetu Przyrodniczo-Humanistycznego w Siedlcach Nr 121, Seria: Administracja i Zarządzanie (48) 2019

Since Georgian consumers in small towns and villages do not have access to international retailers, they are largely unable to complete the act of show-rooming efficiently. Hence, urban consumers who can place orders online and receive the products they ordered are the main focus of this study. Moreover, the younger generation in Georgia was another main concern for the authors since they are the principal users of the internet in the country and simultaneously familiar with the process of exploring different domestic and international online retailers was an important factor as well. According to (Geostat, 2018), 93\% of the population between 15 to 29 years old used the internet in Georgia in three months leading up to July 2018 as opposed to $21 \%$ of the population 60 years and older. Additionally, the same data shows more than $75 \%$ of residents in urban areas used the internet during that period, and the percentage is higher for Tbilisi alone.

However, when it comes to actually purchase goods and services online, the numbers decline, which indicates the potential the market has for growing the online retailing sector. During the same period leading up to July 2018 , more than $31 \%$ of customers aged 15 to 29 placed orders for goods and services online and the number drops down to $17 \%$ for consumers aged 30 to 59 and finally to only $5 \%$ for customers older than 60 . It emphasises the importance of the age range in online shopping and hence the ability to conduct research shopping in general.

Finally, the framework which the semistructured questions are based on is shown below: Variables discussed in the focus groups were divided into utilitarian motivations for show-rooming, such as the price and availability of online outlets, as well as web-rooming product inspection and return policy. On the other hand, hedonistic motivations for show-rooming which mostly refers to innovation and riding the online trend as well as web-rooming motivations which mostly traces its roots back to trust and ease of mind among customers based on the fact that they are able to interact with the retailer directly were discussed. The structure of the focus groups was a more flexible one since the first group were asked about the variables in past literature and with each subsequent group the questions became more comprehensive since the responses of the last group created more detailed topics for the next discussion.

\section{Findings}

The investigation into research shopping indicated a number of interesting factors which motivate the consumers to conduct show-rooming or web-rooming. One way in which all participants were aligned was in whether they conduct research shopping. All participants have done either showrooming or web-rooming at some point.

One of the recurring responses for webrooming was a physical inspection. This utilitarian motivator revealed itself in responses for mostly high-involvement products such as in the clothing or electronic sectors. This positive motivator for physical stores can be found clearly in one of the responses: "I can touch the product and check how fit it is for me, and I can clearly identify whether this shirt is going to suit me or not".

It can also represent itself as a discouragement (negative motivator) from the other side of the spectrum with distrust in online retailers as another participant explained: "I do not trust online products because I cannot physically try the product." Either way, it yields the same result, which means it encourages consumers to stay with the physical stores or conduct web-rooming before making the final purchase at a brick-and-mortar retailer.

Another factor reviewed in other papers concerning show-rooming and the ways to prevent it was utilising travel costs. Consumers in the Georgian market had a more sophisticated view of travel costs based on the culture and infrastructure of the country, specifically in the capital, Tbilisi. On the one hand, some respondents were not concerned about the travel costs and did not find it a factor which can prevent research shopping behaviour. The reason for that, as one participant declared is: "(Travel) cost is not that important because in Georgia there are short distances to shops, so you will not complain I have already use all my expenses to come here.

A more calculating response regarding travel costs was given by another respondent "We can approach it more economically. Like if I already spent 2 hours on it, but it gives me 80 dollars difference online, then I will". However, there were other participants who indicated travel costs could hedonistically affect their decision-making process. One participant who belongs to this group, stated, regarding clothes shopping: "After walking so much and trying to select at the end, I would just get a simple top and get out because I cannot go out empty-handed".

Some motivators balanced each other out and could not be considered a factor in pushing consumers to online or physical outlets. An example 
Tornike K., Arian M., QUALITATIVE INVESTIGATION INTO CONSUMER MOTIVATIONS AND ATTITUDES TOWARDS RESEARCH SHOPPING IN THE GEORGIAN MARKET, Zeszyty Naukowe Uniwersytetu Przyrodniczo-Humanistycznego w Siedlcach Nr 121, Seria: Administracja i Zarządzanie (48) 2019

of that was the way 24 hours availability of online stores, which was regarded as a positive element by the respondent, is offset by long delivery times of online retailers in the country. As one respondent explained how sometimes urgent need for a product could push consumers to place orders on online outlets, however, long delivery times in Georgia render the availability of online retailers pointless in those cases with utilitarian urgency for purchase: "Sometimes, it happens. I will have an important venue next day, so I need to buy clothes" later adding "And it takes ages for them to deliver... they are not even coming to the proper location".

On the other hand, some factors such as privacy issues which are thought to affect the image of online retailers in the literature and specifically in developed countries today, are not as relevant in the Georgian market as of yet. The concern for theft of personal information and credit card numbers by hackers were dismissed as too general and was thought of as more a banking issue. Furthermore, Big data and targeted advertisements were considered a benefit of online outlets rather than a concern as one stated: "It must be there. I prefer to have that... they are making personalised ads for you, it is rather a service for us".

In the case of customer service and sales techniques, consumers distinguished their responses based on the level of involvement in some cases as one declared: "If I have the option to leave the shop like buying Coca Cola then I will. But if I am buying a mobile phone or something and I have chosen it and liked it, and somebody is rude then I will not let them spoil my purchase because I wanted it so I can go and speak to the manager ".

Another concurring issue with customer service was aggressive sales techniques, as one respondent explains: "Sometimes they try hard selling and putting pressure on you so it can cause me not to go around and inspect products in-store".

On the other side of the spectrum, some participants found a proper customer service a motivator in their purchases in physical stores, which prevented them from show-rooming as one asserted: "Sometimes I do not have anything to buy I just want to window shop, but they are coming with smiles like what do you want to try on this is beautiful... and I will be forced just to swipe my credit card and pay for something".

One of the elements which contain both utilitarian and hedonistic roots that affect the consumer decision-making process is the immediate product availability of physical stores. On the utilitarian side, one participant described the motivator in the context of purchasing pharmaceutical products: "Like if I need anything which is important for my health, I immediately go and buy it. I do not want to wait".

On the hedonistic side, there were respondents who explained how instant gratification affect their purchasing decisions and prevent show-rooming behaviour is mostly the clothing sector: "I like to have it (the product) right away I don't like to wait". When asked whether the motive was emotional, the respondent confirmed: "yes, it is emotional".

On other sectors, especially in services, participants were more accepting of online outlets and did not consider web-rooming an option. One of the main sectors in that category was hotel and accommodation. This motivator acted in both an utilitarian way, in speed and comfort of reservations, and a hedonistic way, in the feeling of security and ease, among consumers. It can be summarised in one of the statements: "It is better to go online. It will be quickly organized, when I reach the place it is ready for me it is already there".

A few respondents, who conducted webrooming and purchased those services on the spot, based their behaviour on their prior bad experiences with online outlets: "It happened to me once I booked online, and then I go there, and they said they could not find it" adding: "Because of that any time I want to travel I have to go and find a hotel myself".

Personal factors such as word-of-mouth played another role in reducing research shopping behaviour among customers in the Georgian market. Most of the participants admitted word-ofmouth dampens their show-rooming and webrooming behaviour. It is summarised in one of the statements: "If I hear about a retailer or a restaurant from a friend that has similar interests to me, I do not check for any other retailers online or physically".

Moreover, in the case of food and beverages, switching behaviour in restaurants or the pub sector, was far less than other sectors as one participant expressed: "For me, it is definitely a social experience. And always get the reservation for the brand that I like and go there".

In general, low-involvement products were mostly purchased in physical stores, and switching behaviour was at its lowest in these categories once consumers found the retailer that they liked. The main reason for that was simply put by one respondent: "For groceries, it is complicated to shop online".

Probably the most influential element motivating consumers to conduct show-rooming or web-rooming is the price disparity among different outlets. Naturally, many of the participants admitted they would like to purchase products at lower 
Tornike K., Arian M., QUALITATIVE INVESTIGATION INTO CONSUMER MOTIVATIONS AND ATTITUDES TOWARDS RESEARCH SHOPPING IN THE GEORGIAN MARKET, Zeszyty Naukowe Uniwersytetu Przyrodniczo-Humanistycznego w Siedlcach Nr 121, Seria: Administracja i Zarządzanie (48) 2019

prices, and were willing to switch outlets to find low prices.

In some instances with utilitarian roots, respondents were willing to forego physical inspections of products such as clothing in favour of low prices offered by online retailers. Now only the low prices of online retailers increased show-rooming behaviour, but it can prevent some respondents from switching from one online retailer to another. However, it is applicable to products with low margins as another respondent described her shopping pattern about physical inspection concerns in the clothing sector: "No, because I do not order very expensive clothes online, so it is ok for me".

However, on a more hedonistic level, some respondents were more conscious about the value for the money they spend rather than purely low prices. This view can be best explained in one of the responses: "I do not want to feel fooled. You gave me this swoosh (referring to the Nike logo) on my shoe, and I should pay 80 dollars more, I do not care about the swoosh (referring to the Nike Logo) I need the shoe" when asked whether the product value is the primary factor in his selection of retailers to purchase from he replied. "Yes, so it is not about the money".
Participants did not show great concern about other variables discussed in past literature. As an example, innovation as a hedonistic motivation for shopping online was not a concern among Georgian customers. As for return policy, respondents based their answers on the case by case basis, even though they generally agreed returning defective products to physical stores might be more convenient than the typical return policy of online outlets where the customer is required to mail the product to the retailer and wait for a refund or a new product.

Respondents exhibited slightly different reactions regarding shopping motivations based on nationality as well. For instance, Georgians were not as concerned about customer service quality in physical stores as foreign residents living in the country. It may be a result of Georgian customers being habituated to the culture and customer services in Georgia, while foreign residents constantly contrast their shopping experience in the country with their country of origin. The same ethnocentric view was revealed in delivery times, where foreign residents were more critical of long delivery times by online retailers than Georgian customers.

Table 1. Summary of the findings

\begin{tabular}{|c|c|c|}
\hline Influencing factors & Hedonistic aspect & Utilitarian aspect \\
\hline Physical inspection of products & & $\begin{array}{l}\text { Negatively affects show-rooming } \\
\text { (decreases show-rooming) }\end{array}$ \\
\hline Trust & Negatively affects web--rooming & \\
\hline Travel costs & Negatively affects show-rooming & Negatively affects show-rooming \\
\hline $\begin{array}{l}\text { Working hours ( } 24 \text { hours } \\
\text { availability of online retailers) }\end{array}$ & & $\begin{array}{l}\text { Positively affects web-rooming } \\
\text { (increases web-rooming) }\end{array}$ \\
\hline Privacy and security & Positively affects web-rooming & $\begin{array}{l}\text { In case of personalized } \\
\text { advertisements it negatively affects } \\
\text { web-rooming }\end{array}$ \\
\hline Customer service quality & $\begin{array}{l}\text { Balanced services negatively } \\
\text { affects show-rooming }\end{array}$ & \\
\hline Immediate product availability & $\begin{array}{l}\text { Negatively affects show-rooming } \\
\text { (for customers seeking instant } \\
\text { gratification) }\end{array}$ & $\begin{array}{l}\text { Negatively affects show-rooming } \\
\text { (in emergency purchases) }\end{array}$ \\
\hline $\begin{array}{l}\text { Speed of reservations } \\
\text { (for the service sector) }\end{array}$ & & Negatively affects web-rooming \\
\hline Word of mouth & $\begin{array}{l}\text { Negatively affects both show/ web } \\
\text { - rooming }\end{array}$ & $\begin{array}{l}\text { Negatively affects both show/ web } \\
\text {-rooming }\end{array}$ \\
\hline Brand loyalty & $\begin{array}{l}\text { Negatively affects both show/ web } \\
\text { - rooming }\end{array}$ & $\begin{array}{l}\text { Negatively affects both show/ web } \\
\text { - rooming }\end{array}$ \\
\hline Level of product involvement & & $\begin{array}{l}\text { Positively affects show- rooming } \\
\text { (increases it for high involvement } \\
\text { products }\end{array}$ \\
\hline Price & $\begin{array}{l}\text { Negatively affects show-rooming } \\
\text { (in the case of price parity) }\end{array}$ & $\begin{array}{l}\text { Negatively affects show-rooming } \\
\text { (in case of price parity) }\end{array}$ \\
\hline Return policy & & Negatively affects show-rooming \\
\hline
\end{tabular}




\section{Theoretical implications}

There are few studies done on consumer behavior in the Georgian market and this study is one of the first ones which go into details on the subject. The phenomenon of online shopping is developing and growing in the country and therefore this paper can assist other researchers to find a foundation to explore this area of the market.

Furthermore, this study contributes to other models discovered by other researchers globally with regards to utilitarian and hedonic motivations by linking those shopping patterns to show-rooming and web-rooming phenomena. For instance this study confirms the findings (Sarkar, 2011) indicating the importance of a physical inspection in webrooming behaviour.

As can be observed in the study, the factors discussed are not one dimensional and they mostly have both roots in utilitarian and hedonistic purchases. Hence, this paper can assist in creating multi-dimensional models for different shopping patterns in today's market concerning online and offline retail outlets. As an example, this research finds the importance of online service quality, which was studied by (Homsud and Chaveesuk, 2014), on both utilitarian and hedonistic shopping values specially in hotel and accommodation where the lack of trust can negatively affect customer satisfaction.

Our results indicate some similarity in terms of ethnocentric attitudes discussed by (Kucukemiroglu, 1997) where aspects such as online delivery times and customer service in physical stores were viewed differently among Georgian consumers and foreign residents in the country. However, it differed from Kucukemiroglu's study, which indicated that Turkish customers with ethnocentric tendencies tend to purchase Turkish products. In this aspect Georgian customers were not as concerned about purchasing local products and in some instances they regarded imported goods as having a higher quality.

In addition, our findings determined that Georgian customers can be mostly classified as cosmopolitan consumers regarding their preferred brand and retailers similar to (Shimp and Sharma, 1987; Zeugner-Roth et al., 2015) classification. Ethnocentrism was not apparent in their choice of products; although, in some miniscule ways Georgian customers differed from foreign residents in that they had more favourable views regarding the quality of services provided by online and offline retailers in the country.
Finally, this research attempts to link the retail sector to research shopping behavior through the lenses of utilitarian and hedonistic views. This can illustrate how those shopping patterns branch out in customer's minds and as a result assist in finding a forecasting model for customer behavior in each retail sector. Due to the qualitative nature of this study, a more complicated picture is given by respondents on their values. For instance, this paper found in some retail sectors, such as food and groceries, customer satisfaction and the repurchasing intention is linked to brand loyalty. It is a point of departure from (Dehghana et al., 2015) research which found no significant effect between those variables in Tehran (Iran). Meanwhile, this study confirms the findings of (Nili et al., 2013) which emphasized the role of both utilitarian and hedonistic values that consumers assign to online retailers.

\section{Practical implications}

Further implications of this study can be useful for managerial teams in the retail sector. Managers can utilize this research to find a balance in staff training in order to avoid show-rooming behavior in their offline outlets while preventing salespersons over-engagement with customers which can result in reduced walk-ins.

Another contribution of this study is detailing customer's attitudes towards online and offline stores with regards to product category, speed of delivery and location. Consequently, it can assist managers in product segmentation and optimizing the distance of offline outlets from customer's homes and work places. In this regard, this paper finds similar themes with (Rintamäkia and Kirvesb, 2017) researching U.S, Japan and Finland on the importance of segmentation and nature of outlet in the retail industry and its influence on customer values.

Moreover, the paper compliments the findings of (Çala, and Adams, 2014) for the Georgian market. Their findings stressed the importance of utilitarian values of Turkish consumers, meanwhile this research found similar themes with Georgian consumers as well as new themes on their hedonistic views.

Lastly, opinions expressed in this study reveal more sophisticated attitudes towards pricing in the retail sector. It enables managers to design their pricing and promotions based on a more complex platform by considering the utilitarian and hedonistic views of consumers towards prices. 
Tornike K., Arian M., QUALITATIVE INVESTIGATION INTO CONSUMER MOTIVATIONS AND ATTITUDES TOWARDS RESEARCH SHOPPING IN THE GEORGIAN MARKET, Zeszyty Naukowe Uniwersytetu Przyrodniczo-Humanistycznego w Siedlcach Nr 121, Seria: Administracja i Zarządzanie (48) 2019

\section{Conclusion and recommendation}

As can be observed, there is a number of factors which can sway consumers in their interchanging behaviour to either physical stores or online outlets. Leveraging these factors can assist retailers in reducing the research shopping behaviour among Georgian customers. Some of these elements, such as immediate product availability of physical retailers, can be leveraged in both utilitarian and hedonistic manners. Meanwhile, some of the benefits of online retailers such as 24 hours availability was weighed down by the lack of proper customer service and long delivery processes.

The study suggests leveraging lower prices, reducing delivery times and developments in certain sectors such as hotel and accommodation for online outlets in order to increase their growth and reduce web-rooming. Simultaneously, physical stores can decrease show-rooming by leveraging their benefits from enabling customers to inspect the product to optimising sales techniques and customer services, engaging in low-involvement products and as previously mentioned, immediate product availability.

For future research, the authors recommend a quantitative study on these factors in the Georgian market so the effect of each one of the elements discussed in this study can be empirically measured. Furthermore, during the inspection, the authors realised web-rooming is more common than show-rooming in the Georgian market, and hence another recommendation is to study webrooming behaviour in more detail, alone, in both utilitarian and hedonistic levels.

\section{References}

Abdul-Muhmin, A. (2011). Repeat purchase intentions in online shopping: the role of satisfaction, attitude, and online retailers' performance. Journal of International Consumer Marketing, 23 (1), 5-20.

Amaxilatis, D., \& Giannakopoulou, K. (2018). Evaluating retailers in a smart-buying environment using smart city infrastructures. IEEE International Conference on Pervasive Computing and Communications, (p. DOI: 10.1109/PERCOMW 2018.8480304). Athens.

Blázquez, M. (2014). Fashion shopping in multichannel retail: the role of technology in enhancing the customer experience. International Journal of Electronic Commerce, 18 (4), 97-116.

Brown, T., Friedman, D., \& Taran, Z. (2013). Showrooming and the small retailer: setting a research agenda. In D. DeLong, D. Edmiston, \& C. Trimble (Ed.), Staying Current with Media \& Millennials (pp. 46-49). Marketing and Management Association 2013.
Çala, B., \& Adams, R. (2014). The effect of hedonistic and utilitarian consumer behavior on brand equity: Turkey - UK Comparison on Coca Cola. 10th International Strategic Management Conference. 150, pp. 475-484. Elsevier.

Chung, S., Chakravarti, A., \& Zwick, R. (2016). It feels softer than it looked: contrast-priming effects of touch-screen users in multi-channel shopping. Association for Consumer Research, 44, 225-230.

Coulthard, D., Castleman, T., \& Batten, L. (2004). E-commerce strategy In A multi-sector trading environment - quandaries For SMEs. Bled Electronic Commerce Conference (pp. 1-13). Bled: eGlobal.

Datta, Y. (2010). A critique of Porter's cost leadership and differentiation strategies. Chinese Business Review, 9 (4), 37-51.

Dehghan, N., Alizadeh, H., \& Mirzaei-Alamouti, S. (2015). Exploring the customer percieved values as antecedent of purchase behavior. Serbian Journal of Management, 10 (2), 173-188.

Donnelly, C., \& Scaff, R. (2013). Who are the Millennial shoppers? And what do they really want?. The journal of high-performance business, 1 (2).

Erdil, T. (2015). Effects of customer brand perceptions on store image and purchase intention: An application in apparel clothing. 11th International Strategic Management Conference (pp. 196-205). Istanbul: Elsevier.

Flavian, C., Gurrea, R., \& Orus, C. (2016). Choice confidence in the webrooming purchase process: the impact of online positive reviews and the motivation to touch. Journal of Consumer Behaviour, DOI: 10.1002/cb.1585.

Gensler, S., Nelsin, S., \& Verhoef, P. (2017). The showrooming phenomenon: it's more than just about price. Journal of Interactive Marketin, 38 (1), 29-43.

Geostat. (2019, February 13). Information Communication Technology. Retrieved June 7, 2019, from www.geostat.ge: https://www.geostat.ge/ en/modules/categories/106/information-and-communication-technologies-usage-in-households

Gu, Z., \& Tayi, G. (2016). Consumer Pseudo-Showrooming and Omni-Channel Product.

Guest, G., Namey, E., \& McKenna, K. (2017). How many focus groups are enough? building an evidence base for nonprobability sample sizes. Sage journals, 29 (1), 3-22.

Hadi, R., \& Valenzuela, A. (2016). Good vibrations: consumer responses to technologically-mediated social touch. Association for Consumer Research, 44, 225-230.

Herring, L., Wachinger, T., \& Wigley, C. (2014, December). Making stores matter in a multichannel world. Retrieved May 21, 2019, from https://www.mckinsey.com/, https://www.mckinsey. com/industries/retail/our-insights/making-storesmatter-in-a-multichannel-world.

Hilken, T., Heller, J., Chylinski, M., Keeling, D., \& Mahr, D. (2018). Making omnichannel an augmented reality: the current and future state of the art. 
Tornike K., Arian M., QUALITATIVE INVESTIGATION INTO CONSUMER MOTIVATIONS AND ATTITUDES TOWARDS RESEARCH SHOPPING IN THE GEORGIAN MARKET, Zeszyty Naukowe Uniwersytetu Przyrodniczo-Humanistycznego w Siedlcach Nr 121, Seria: Administracja i Zarządzanie (48) 2019

Journal of Research in Interactive Marketing, $12(4), 509-523$.

Homsud, S., \& Chaveesuk, S. (2014). Understanding a proposed model of customer loyalty formation in B2C e-commerce. International Journal of Future Computer and Communication, 3 (3), 191-197.

Ivanauskienè, N., Auruškevičienè, V., Škudienè, V., \& Nedzinskas, Š. (2012). Customer perceptions of value: case of retail banking. Organizations and Markets in Emerging Economies, 3 (1), 75-89.

Kang, J.M. (2017). Social-local-mobile consumers' fashion lifestyle and Omnichannel shopping. International Textile and Apparel Association Annual Conference. 24. St. Petersburg, Florida: lowa State University.

Kang, J. (2014). Showrooming, webrooming, and user-generated content creation: the moderating effect of SoLoMo. International Textile and Apparel Association (ITAA) Annual Conference. 43, pp. 31-32. International Textile and Apparel Association.

Khan, S., Liang, Y., \& Shahzad, S. (2015). An empirical study of perceived factors affecting customer satisfaction to re-purchase intention in online stores in China. Journal of Service Science and Management, 8 (1), 291-305.

Kucukemiroglu, O. (1997). Market segmentation by using consumer lifestyle dimensions and ethnocentrism An empirical study. European Journal of Marketing, 33 (5/6), 470-487.

Lee, J., \& Cormier, J. (2010). Effects of consumers' demographic profile on mobile commerce adoption. Journal of Distribution Science, 8(1), 5-11.

Lim, W. (2014). Understanding the influence of online flow elements on hedonic and utilitarian online shopping experiences: a case of online group buying. Journal of Information Systems, 28 (2), 287-306.

Luo, Q., Oh, L., Zhang, L., \& Chen, J. (2014). Examining the showrooming intention of mobileassisted shoppers in a multichannel retailing environment. PACIS 2014 Proceedings. 141, pp. 141-153. Chengdu: Association for Information Systems AIS Electronic Library.

Machavolu, S., \& Raju, K. (2014). Showrooming: the next threat to Indian retail. MIJBR, 1 (1).

Mehra, A., Kumar, S., \& Raju, J. (2017). Competitive strategies for brick-and-mortar stores to counter "showrooming". Management Science, 64 (7).

Menon, S., \& Kahn, B. (2002). Cross-category effects of induced arousal and pleasure on the internet shopping experience. Journal of Retailing, 78 (1), 31-40.

Minh, D. (2015). The trend of showrooming and webrooming behaviors of the consumers in Ho Chi Minh City. The 3rd IBEA International Conference on Business, Economics and Accounting, (pp. 15-17 Ho Chi Minh.

Mosquera, A., Ayensa, E., Murillo, Y., \& Pascual, C. (2018). Identifying omnichannel customer segments regarding the perceived usefulness, shopping enjoyment, and social influence.
Sustainable business models: integrating employees, customers and technology, (pp. 41-45). Madrid.

Nayyar, R., \& Gupta, S. L. (2010). Impact of changing demographic profiles of Indian customers on their internet shopping behaviour. ViewPoint, 17-24.

Nesar, S., \& Bin Sabir, L. (2016). Evaluation of customer preferences on showrooming and webrooming: an empirical study. Al-Barkaat Journal of Finance \& Management, 8 (1), 50-67.

Nili, M., Delavari, D., Tavassoli, N., \& Barati, R. (2013). Impacts of utilitarian and hedonistic values of online shopping on preferences and intentions of consumers. International Journal of Academic Research in Business and Social Sciences, 3 (5), 82-93.

Okada, E. (2005). Justification effects on consumer choice of hedonic and utilitarian goods. Journal of Marketing Research, 42 (1), 43-53.

Pei, Z., Paswan, A., \& Yan, R. (2014). E-tailer's return policy, consumer's perception of return policy fairness and purchase intention. Journal of Retailing and Consumer Services, 21 (1), 249-257.

Powell, R., \& Single, H. (1996). Methodology matters$\mathrm{V}$ focus groups. International Journal For Quality In Health Care, 8 (5), 499-504.

Rapp, A., Baker, T., Bachrach, D., Ogilvie, J., \& Beitelspacher, L. (2015). Perceived customer showrooming behavior and the effect on retail salesperson self-efficacy and performance. Journal of Retailing, 91 (2), 358-369.

Reid, L., Ross, H., \& Vignali, G. (2016). An exploration of the relationship between product selection criteria and engagement with 'show-rooming' and 'web-rooming' in the consumer's decision-making process. International Journal of Business and Globalisation, 17 (3), 364-383.

Reyes-Menendez, A., Palos-Sanchez, P., Saura, J., \& Martin-Velicia, F. (2018). Understanding the influence of wireless communications and $\mathrm{Wi}-\mathrm{Fi}$ access on customer loyalty: a behavioral model system. Wireless Communications and Mobile Computing, 1-16.

Rigby, D. (2011). The Future of Shopping. Harvard Business Review, 89 (12), 65-76.

Rintamäki, T., \& Kirves, K. (2017). From perceptions to propositions: profiling customer value across retail contexts. Journal of Retailing and Consumer Services, 37, 159-167.

Sahney, S., Ghosh, K., \& Shrivastava, A. (2013). Buyer's motivation" for online buying: an empirical case of railway e- icketing in Indian context. Journal of Asia Business Studies, 8 (1), 43-64.

Sarkar, A. (2011). Impact of utilitarian and hedonic shopping values on individual's perceived benefits and risks in online shopping. International Management Review, 7 (1), 58-66.

Scarpi, D. (2012). Work and fun on the internet: the effects of utilitarianism and hedonism online. Journal of Interactive Marketing, 26 (1), 53-67. 
Shimp, T., \& Sharma, S. (1987). Consumer ethnocentrism: construction and validation of the CETSCALE. Journal of Marketing Research, 24, 280-89.

Sinha, P., \& Singh, S. E-retailing in developing economy - a study on consumers' perceptions. Academy of Marketing Studies Journal, 20 (3), 6273.

Strom, R., Vendel, M., \& Bredican, J. (2014). Mobile marketing: A literature review on its value for consumers and retailers. Journal of Retailing and Consumer Services, 21 (1), 1001-1012.

Su, H., Fang, F., Qian, D., \& Yu, K. (2013). Empirical study of hedonic and utilitarian attitudes toward network consumption. International Academic Workshop on Social Science (pp. 732-736). Atlantis Press.

Venkatesan, R., Kumar, V., \& Ravishanker, N. (2007). Multichannel shopping: causes and consequences. Journal of Marketing, 71 (1), 114-132.

Vijayalakshmi Menon, P., Barani, G., \& Suganthalakshmi, T. (2018). Mapping customer shopping attitude towards webrooming technique. International Journal of Pure and Applied Mathematics, 119 (12), 991-1003.

Wang, C., \& Wright, J. (2015). Search platforms: showrooming and price parity clauses. Working paper.

Wu, C., Wang, K., \& Zhu, T. (2015). Can price matching defeat showrooming? Ottawa: Social Sciences and Humanities Research Council.
Yrjölä, M. (2014). Value creation challenges in multichannel retail business models. Journal of Business Models, 2 (1), 89-104.

Zalega, T. (2017). Smart shopping in consumer behaviour of Polish seniors (report from own research). Acta Sci. Pol. Oeconomia, 16 (3), 101 -110 .

Zeugner-Roth, K., Žabkar, V., \& Diamantopoulos, A. (2015). Consumer ethnocentrism, national identity, and consumer cosmopolitanism as drivers of consumer behavior: a social identity theory perspective. Journal of International Marketing, 23 (2), 25-54.

Zhang, J., Farris, P., Irvin, J., Kushwaha, T., Steenburgh, T., \& Weitz, B. (2010). Crafting integrated multichannel retailing strategies. Interactive Marketing, 24, 168-180. 